Provided for non-commercial research and education use. Not for reproduction, distribution or commercial use.

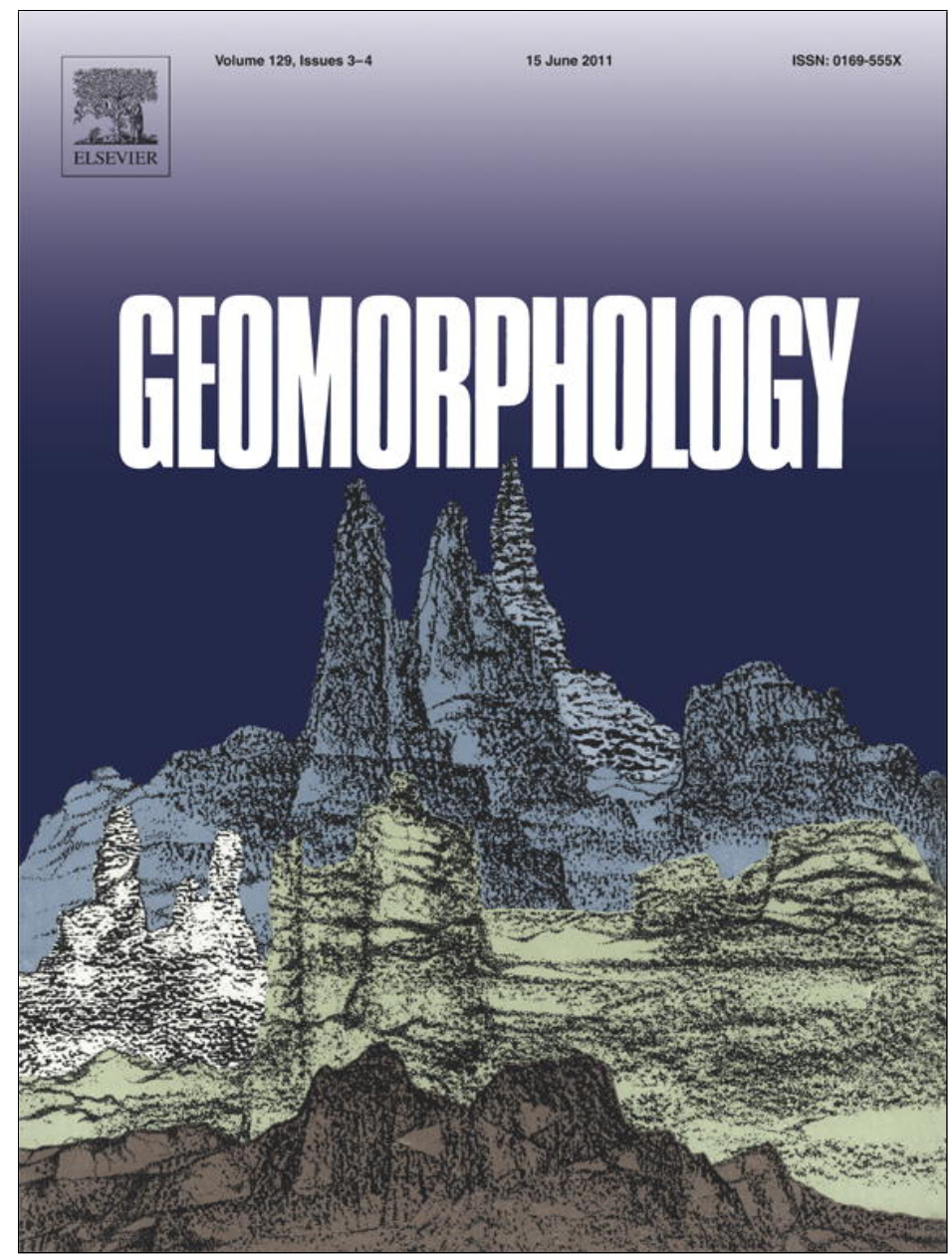

This article appeared in a journal published by Elsevier. The attached copy is furnished to the author for internal non-commercial research and education use, including for instruction at the authors institution and sharing with colleagues.

Other uses, including reproduction and distribution, or selling or licensing copies, or posting to personal, institutional or third party websites are prohibited.

In most cases authors are permitted to post their version of the article (e.g. in Word or Tex form) to their personal website or institutional repository. Authors requiring further information regarding Elsevier's archiving and manuscript policies are encouraged to visit:

http://www.elsevier.com/copyright 


\title{
An integrated approach to coastal erosion problems in northern Tuscany (Italy): Littoral morphological evolution and cell distribution
}

\author{
G. Anfuso ${ }^{\mathrm{a}, *}$, E. Pranzini ${ }^{\mathrm{b}, 1}, \mathrm{G}$. Vitale ${ }^{\mathrm{b}, 1}$ \\ a Departamento de Ciencias de la Tierra, Facultad de Ciencias del Mar y Ambientales, Universidad de Cádiz, Polígono Río San Pedro s/n, 11510 Puerto Real (Cádiz), Spain \\ b Dipartimento di Scienze della Terra, Università degli Studi di Firenze, Borgo Albizi 28, 50122 Firenze, Italy
}

\section{A R T I C L E I N F O}

\section{Article history:}

Received 9 September 2010

Received in revised form 27 January 2011

Accepted 31 January 2011

Available online 25 February 2011

\section{Keywords:}

Littoral

Erosion

Cell

Human-made structures

Tuscany

Italy

\begin{abstract}
A B S T R A C T
Occupation of the coast has significantly increased in recent decades, mostly due to a greater demand for recreation and tourism. Today, erosion threatens many human-made structures and activities, requiring an integrated approach for the understanding of coastal dynamics and identification of alternatives to associated problems. This study investigates a $64 \mathrm{~km}$-long coastal physiographic unit in the northern microtidal littoral of Tuscany (Italy). Vertical aerial photographs and direct field surveys were used to retrieve changes in shoreline position over 1938-1997 and 1997-2005 time intervals. Significant beach accretion was observed during the first period updrift of Carrara $(84 \mathrm{~m})$ and Viareggio $(280 \mathrm{~m})$ harbours and at Marina di Pietrasanta $(100 \mathrm{~m})$, whereas severe erosion occurred downcoast of Carrara harbour ( $-130 \mathrm{~m}$, at Marina dei Ronchi) and on the northern side of Arno river mouth $(-400 \mathrm{~m})$. Similar trends were observed between 1997 and 2005 ; beach slope between the 1997 shoreline position and the closure depth correlated well with the distribution of erosion/accretion patterns from the 1938-1997 period (slopes were lower in eroded areas than at sites under accretion). Longshore distribution of erosion/accretion patterns was controlled by coastal compartmentalisation. Three of the main littoral cells were mostly formed by natural limits (i.e., Punta Bianca promontory, Marina di Pietrasanta, the Arno river mouth and the port of Livorno). Several sub-cells were created within these cells due to the introduction of human-made structures (such as Carrara and Viareggio harbours), which formed artificial fixed limits that allowed the transport of sediments (exclusively fines) in one direction only. Results will help improve the understanding of coastal processes and manage littoral sediment transport in a sustainable manner. This will reduce the need for structural interventions, such as breakwaters and groynes, which in the past decades prevented coastal retreat at local scale but shifted erosion downdrift, leading to degradation of the investigated area and requiring continuous maintenance.
\end{abstract}

(C) 2011 Elsevier B.V. All rights reserved.

\section{Introduction}

The $64 \mathrm{~km}$-long coastal physiographic unit located in the northern littoral of Tuscany, Italy (Fig. 1) recorded significant erosion problems in recent decades due to reduction in sediment input from rivers (Pranzini, 2001) and to the feeding effect of harbours, ports and shore protection structures (Cipriani et al., 2001).

Recent studies based on the evolution of the shoreline (defined as the zero isobath position) from 2000 to 2010 show that circa 38.6\% of this coast experienced severe erosion in the period, reaching $20 \mathrm{~m} \mathrm{yr}^{-1}$ at some sites. Regional administration authorities are currently spending approximately 65 million Euros in the execution of nine shore protection projects-as a measure to counteract erosion

\footnotetext{
* Corresponding author. Tel.: + 34 956016447; fax: + 34956016288

E-mail addresses: giorgio.anfuso@uca.es (G. Anfuso),enzo.pranzini@unifi.it (E. Pranzini), giovanni.vitale79@gmail.com (G. Vitale).

1 Tel.: + 390552479241 ; fax: + 390552479741 .
}

and reduce its negative impact on tourism, which is the main economic activity in this part of the coast (Sargentini et al., 2004).

Such interventions, all part of a regional erosion management plan of 107 million Euros, may trigger important changes in coastal dynamics. These have already been modified from the natural condition by the construction of $16 \mathrm{~km}$ of hard engineering structures which started in the beginning of the 20th century (such as seawalls, rip-rap revetments, detached breakwaters, groynes, and submerged structures). Most of these structures will now be reduced in size or in height, and some new structures will be built, whereas artificial nourishment will be carried as the main defence strategy (Aminti et al., 2003).

A regional framework was evaluated in order to reach an appropriate design for coastal defence structures, following guidelines adopted by several authors (e.g., Bray et al., 1991; Pilkey and Dixon, 1996; Berlanga and Ruiz, 2002; Cooper and Pethick, 2005). This assessment included estimation of sediment input and output, determination of erosion/accretion areas, and the identification of sediment transport pathways and distribution of littoral cells. 

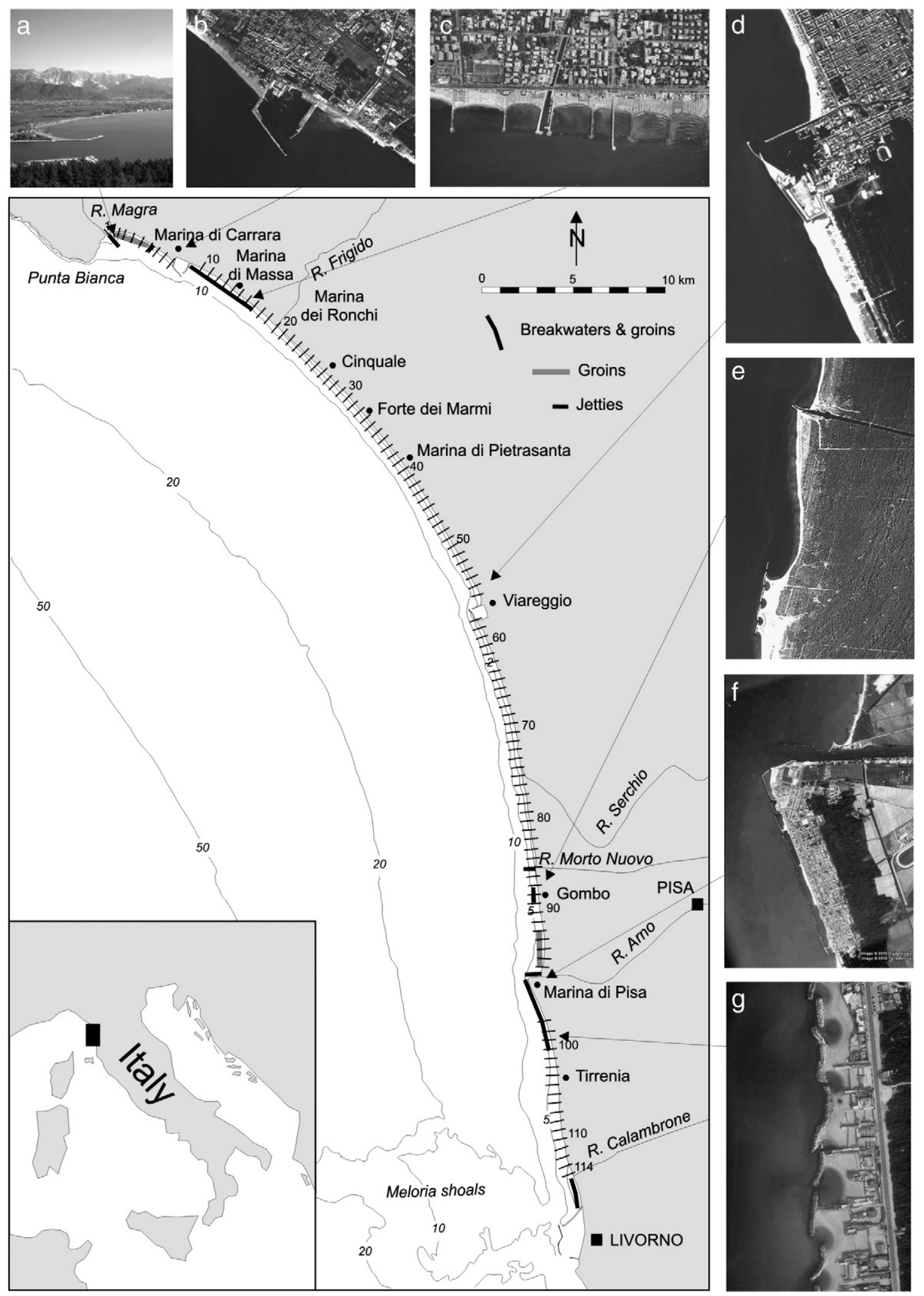

Fig. 1. Location map with major coastal villages, protection structures and sectors used in the study of coastal evolution (see tickmarks along the coast). Bathymetric contours are also presented. Photographs show the Magra river mouth (a), Marina di Carrara harbour (b), Marina di Massa (c), Viareggio harbour (d), the Gombo and Morto Nuovo river mouths (e), the Arno river mouth (f) and the southern area of Marina di Pisa (g).

A budgetary approach was considered in this coastal area to further a quantitative assessment of sediment inputs/outputs and transport pathways within each littoral cell; transfer processes, which operate over a range of spatial and temporal scales, were also investigated between adjacent cells (Regione Toscana, 2006). This follows the concept where understanding the distribution and characteristics of 
littoral cells is essential for appropriate coastal erosion management plans, which must be organised at a large, regional scale (Fischer, 1985; Carter, 1988; Bray et al., 1995).

Small-scale analysis of the cell system within this physiographic unit had not yet been performed, considering the inter-relationship between current processes and the different coastal structures built along the coast. The analysis of this relationship will help local government planners define the final coastal defence configuration and implement a monitoring system capable of improving the understanding of beach response to new projects.

\section{Study area}

The investigated area is approximately $64 \mathrm{~km}$ long and is located between Punta Bianca and the port of Livorno, in NW Italy (Fig. 1). The regions of Liguria $(2.5 \mathrm{~km})$ and Tuscany $(61.5 \mathrm{~km})$ are administratively responsible for this part of the coast.

\subsection{The physical environment}

Coastal orientation varies from NW-SE, in the northern sector, to $\mathrm{N}-\mathrm{S}$, in the southern part. Except for the northern sector, which consists of mixed sand and gravel, the coast is mostly composed of dissipative sandy beaches of varying width, rich in quartz and carbonates, but also containing feldspars and heavy minerals (Gandolfi and Paganelli, 1975; Garzanti et al., 2001).

The coastal plain is mostly formed of sediment supplied by the Arno and Magra rivers, whereas the Serchio and Frigido rivers represent secondary sediment sources; other minor streams, mostly located in the northern sector, provide very limited contribution to the sediment yield. The Arno is the most important river, with a total sediment load of circa 1,524,000 $\mathrm{t} \mathrm{yr}^{-1}$ (Cavazza, 1984; Becchi and Paris, 1989). The Marga and Serchio rivers supply 632,000 and $23,000 \mathrm{t} \mathrm{yr}^{-1}$-, respectively (Cavazza, 1984). It is important to note that river sediment supply was largely reduced in the past century due to reforestation within watersheds, river bed quarrying, and construction of weirs and dams (Pranzini, 1994). This was the case of the River Arno, where sediment input had been approximately $5,150,000 \mathrm{~m}^{3} \mathrm{yr}^{-1}$ (c. $9,300,000 \mathrm{t} \mathrm{yr}^{-1}$ ) during the $1500-1800 \mathrm{AD}$ period (Becchi and Paris, 1989).

The coast is microtidal, with an astronomical tidal range of $35 \mathrm{~cm}$ (Istituto Idrografico della Marina, 2003), to which an atmospheric component of +20 and $-18 \mathrm{~cm}$ must be added according to possible pressure values in this part of the Liguria Sea $(\mathrm{P}<994 \mathrm{hP}$ and $\mathrm{P}>1031 \mathrm{hP}, 1 \%$ and $99 \%$ of the frequency distribution based on 64,988 observations at Marina di Carrara harbour from January 2006 to October 2009). Wind and wave data, respectively hindcasted by ECMWF (European Centre for Medium-range Weather Forecast, 2008) and WAM (WAve prediction Model; WAM-Development and Implementation Group, 1988) and related to the 1992-2004 period, have been analysed by means of numerical models (De Filippi et al., 2008).

A wind set-up value of $67 \mathrm{~cm}$ for a 50 -yr return period of $240^{\circ}$ winds was computed. Significant wave height $\left(\mathrm{H}_{\mathrm{s}}\right)$ and period $\left(\mathrm{T}_{\mathrm{s}}\right)$ for the same event were $7.54 \mathrm{~m}$ and $9.15 \mathrm{~s}$ respectively.

The wave rose for $H_{s}$ values greater than $0.5 \mathrm{~m}$ for nearshore waters (20 m water depth) at Viareggio (the central part of the study area) is presented in Fig. 2. Taking into account the entire data set over the 1992-2004 period, i.e. including also $\mathrm{H}_{\mathrm{s}}$ values lower than $0.5 \mathrm{~m}$., the most frequent (46.55\%) and severe $\left(\mathrm{H}_{\mathrm{s}} 4.50 \mathrm{~m}\right.$ for $0.11 \%$ of the time) storms arrived from the $240^{\circ}$ direction, with extremely high sorting (secondary direction of $180^{\circ}$ with $11.65 \%$ frequency, and $3.5 \mathrm{~m}$ waves for only $0.01 \%$ of the time). Considering these wave data, De Filippi et al. (2008) obtained a value of $9.1 \mathrm{~m}$ for the depth of closure according to the Hallermeier (1981) formulation.

\subsection{Coastal occupation and shore protection}

The northern sector of this physiographic unit exhibits a high level of urbanisation near the harbours of Carrara (mostly used for cargo shipping) and Viareggio (due to recreational and fishing activities). On the northern part, a $30 \mathrm{~km}$ long tourist district connecting Marina di Carrara, Marina di Massa, Forte dei Marmi and Viareggio consists mainly of summer residences, hotels and other recreational structures available to fulfil the local demand from tourists, including people who move temporarily to the coast during summer, and other more occasional visitors. The southern sector, at the Arno river mouth, has a lower level of human occupation and hosts a natural protected area within the San Rossore Regional Park. Only two settlements are present in the area: Marina di Pisa village, developed on the southern lobe of the Arno river delta in the second half of the 19th century, and Tirrenia, which emerged after a US military base settled on this part of the coast (Fig. 1).

During the second half of the 19th century, when the coast was mostly uninhabited, erosion started at the Magra and Arno river mouths (Fig. 1 a, f)-however, the southern lobe of the Arno river delta soon became protected due to the development of Marina di Pisa. During recent decades, erosion processes occurred downdrift of harbours and other engineering structures (Fig. 1 b, d), which had been built at very specific sites as a solution to urgent local erosion problems. Almost all types of protective structures were constructed along this coast: groynes, detached breakwaters and artificial islands (Fig. $1 \mathrm{c}, \mathrm{e}, \mathrm{g}$ ); seawalls and rip-rap revetments (usually built in very narrow coastal sectors as protection to coastal roads such as Marina di Carrara or coastal settlements such as Marina di Pisa); and jetties (constructed at many river mouths) (Fig. 1 a, e, f). The characteristics and location of the main defence structures are presented in Table 1.

Alternative measures, such as nearshore scraping (Cipriani et al., 1999), construction of submerged geotextile groynes (Aminti et al., 2004) and creation of gravel beaches (Cammelli et al., 2006) were undertaken in the past decade. An obstacle to choosing beach nourishment as a strategy may come from the elevated costs of sediments used $\left(23-30 € / \mathrm{m}^{3}\right)$, as coarse material is only available from land deposits since river bed quarrying is no longer allowed in Tuscany. The latest nourishment project executed with fine sediment in Tuscany (at Marina di Carrara, from February 2006 to February 2008) used sand from the Po River alluvial plain, located at a distance of circa $200 \mathrm{~km}$; the cost was lower than expected $\left(18 € / \mathrm{m}^{3}\right)$ since lorries used for transport would have otherwise returned empty to Marina di Carrara after delivering marble blocks in the north of Italy (Ferri et al., 2008). Sand dredged offshore is usually a cheaper option in Italy, with prices ranging between $16 € / \mathrm{m}^{3}$ in Emilia-Romagna in 2007 (Preti, 2009) and $7 € / \mathrm{m}^{3}$ in Lazio in 2004.

\section{Methodology}

Aerial photographs and topographic maps from different years and of varying scales, as well as direct surveys, have been used to characterise coastal evolution and the shoreline position trend at short- and medium-term scales ( $<10$ yrs and between 10 and $60 \mathrm{yrs}$. respectively, sensu Crowell et al., 1993).

The Dipartimento di Scienze della Terra dell'Università di Firenze (1989) had already obtained the shoreline position for 1938,1967, 1978 and 1985 through photogrammetric restitution at 1:5000 scale from low to medium altitude flights.

Concerning field surveys, a total station and an RTK-GPS were used to determine shoreline position (i.e. the zero metre isobath) in 1997 and 2005. According to Dolan et al. (1991), the effects of seasonal variation and the influence of individual storms on shoreline evolution have limited importance when the duration of such a time span is considered. 


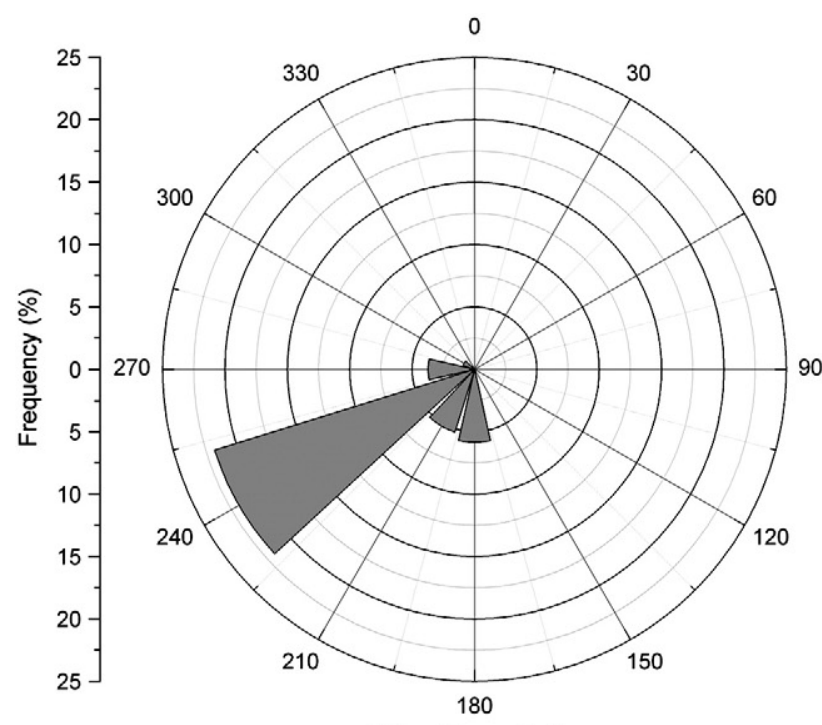

$0.5<\mathrm{Hs} \leqslant 1.5 \mathrm{~m}$

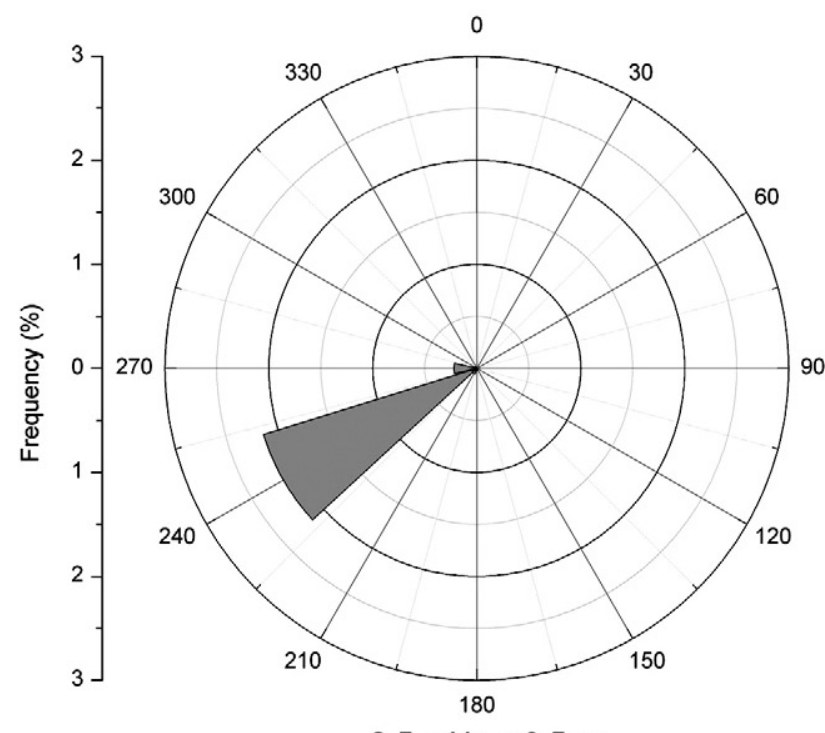

$2.5<\mathrm{Hs} \leqslant 3.5 \mathrm{~m}$

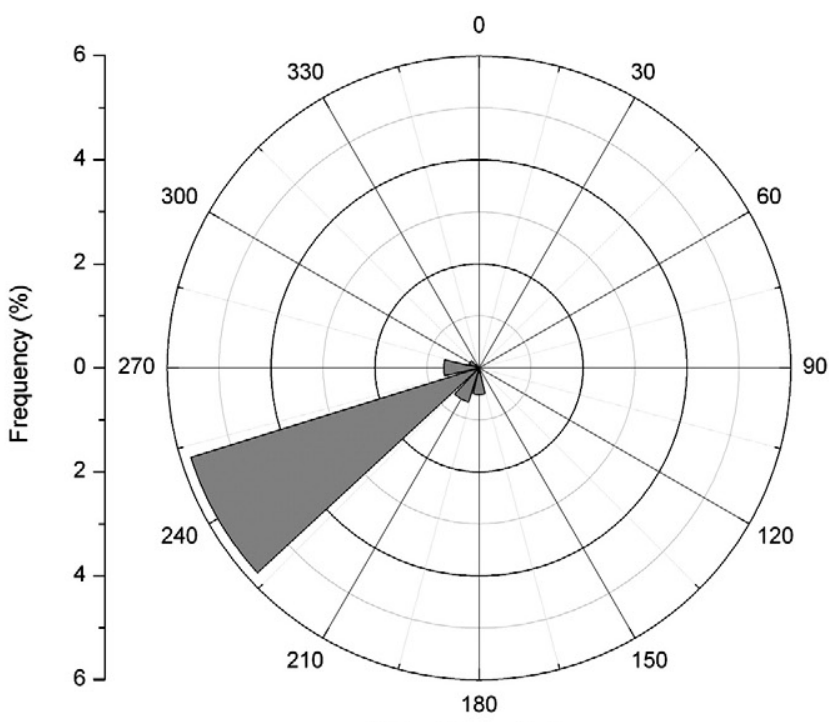

$1.5<\mathrm{Hs} \leqslant 2.5 \mathrm{~m}$

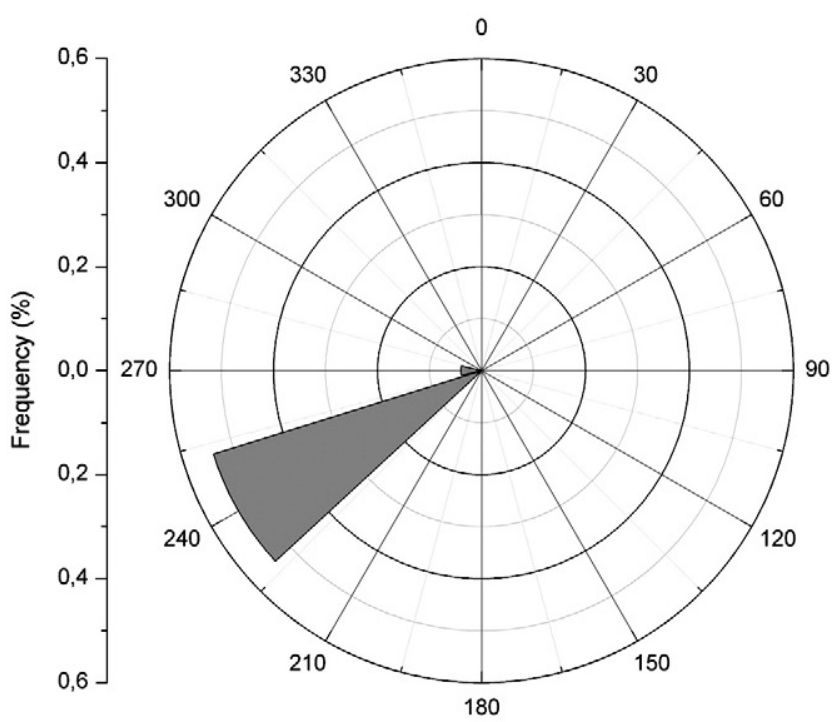

$3.5<\mathrm{Hs} \leqslant 4.5 \mathrm{~m}$

Fig. 2. Wave roses for different $\mathrm{H}_{\mathrm{s}}$ in $20 \mathrm{~m}$ water depth at Viareggio derived from the European Centre for Medium-range Weather Forecast (ECMWF) data (1992-2004). Different frequency scales in each graph.

Total shoreline mapping error from remotely sensed images, due to astronomical and barometric tides, and photo-restitution accuracy, were assumed to be $\pm 5 \mathrm{~m}$ (Bartolini et al., 1989). Changes lower than $10 \mathrm{~m}$ were, therefore, not considered to be representative of surveyed shoreline displacements.

Bathymetric surveys were also carried out in 1997 and extended up to $10 \mathrm{~m}$ in water depth; beach slope was calculated between the shoreline and the depth of closure ( $9.1 \mathrm{~m})$. A VanVeen bucket was used to collect 703 sediment samples along the study area, which were sieved in the laboratory at 10 min period with $1 / 2$ phi sieve intervals. Standard sediment statistics were used to calculate the value of the grain size parameters such as mean size and sorting (Folk and Ward, 1957).

The determination of littoral cell parts and limits can follow morphological, sedimentological and/or hydrodynamic criteria (May

Table 1

Coastal protection structures in the study area.

\begin{tabular}{|c|c|c|c|c|}
\hline Location & Type & Material & Number & Total length $(\mathrm{m})$ \\
\hline Bocca di Magra-Carrara harbour & $\begin{array}{l}\text { Jetties, artificial islands, detached breakwaters, emerged and } \\
\text { submerged groynes }\end{array}$ & Rocky blocks, concrete diecast & 19 & 950 \\
\hline Carrara harbour-M. di Massa-M. dei Ronchi & $\begin{array}{l}\text { Seawalls, rip-rap, groynes, detached breakwaters, submerged } \\
\text { breakwaters, submerged groynes }\end{array}$ & Rocky blocks, geotextile bags & 33 & 4500 \\
\hline Fiume Morto Nuovo-Arno River mouth & Jetties, detached breakwaters, groynes & Rocky blocks & 17 & 1430 \\
\hline M. di Pisa & Seawalls, detached breakwaters, groynes, gravel nourishment, & Rocky blocks, marble gravel & 22 & 2800 \\
\hline Marina di Pisa-Tirrenia & Groynes, detached breakwaters, submerged breakwaters & Rocky blocks & 18 & 1101 \\
\hline
\end{tabular}


and Tanner, 1973; Lowry and Carter, 1982; Carter, 1988); this study used morphological criteria to determine the different parts of a single littoral cell, and placed cell limits at points of discontinuity regarding the direction of sediment transport (Bray et al., 1995).

\section{Results and discussion}

\subsection{Coastal evolution}

The study of coastal evolution was centred on two periods:

i) 1938-1997 (a period during which most shore protection structures and all harbours were constructed), for studies of medium term evolution;

ii) 1997-2005 (when no important projects were implemented), for analysis of current trends.

Coastal evolution during both periods is presented for 114 coastal sectors of $500 \mathrm{~m}$ length each (Fig. $3 \mathrm{a}, \mathrm{b}$ ).

From 1938 to 1997, continuous coastal accretion was observed north of the Carrara harbour, at the updrift dock (maximum values of $85 \mathrm{~m}$, i.e., $1.4 \mathrm{~m} \mathrm{yr}^{-1}$ ); along a $12 \mathrm{~km}$-long structure-free stretch at Marina di Pietrasanta (maximum values of $100 \mathrm{~m}$, i.e., $1.7 \mathrm{~m} \mathrm{yr}^{-1}$ ); and south of the Viareggio harbour, at the updrift dock (maximum values of $280 \mathrm{~m}$, i.e., $7.7 \mathrm{~m} \mathrm{yr}^{-1}$ ) (Figs. $1 \mathrm{~b}, \mathrm{~d}$, and $3 \mathrm{a}$ ). Accretion was observed also in the area of Gombo (sector n. 89, Figs. 1 e, and 3 a), where five detached breakwaters had been built in the early 1960s to protect the beach in front of the Presidential villa (Bowman and Pranzini, 2003).
The main erosion areas were recorded in Marina di Massa and Marina dei Ronchi (with maximum values of 110 and 50 m, i.e., 1.8 and $0.8 \mathrm{~m} \mathrm{yr}^{-1}$, respectively); along the sector between the Serchio and Arno river mouths (with maximum values of $400 \mathrm{~m}$, or $6.8 \mathrm{~m} \mathrm{yr}^{-1}$ ) (Figs. $1 \mathrm{c}$, e, and $3 \mathrm{a}$ ); and on the southern coast of Marina di Pisa (average erosion rate of circa $1 \mathrm{~m} \mathrm{yr}^{-1}$, corresponding to an average retreat of $60 \mathrm{~m}$ ).

The coastal evolution trend was updated considering the 19972005 period (Fig. 3 b): erosion-accretion patterns followed perfectly the trends observed in the previous period. However, the main differences were noted as:

i) Marina dei Ronchi and south of Marina di Pisa, where retreat was halted by the construction of protective structures which shifted erosion downdrift. At Marina dei Ronchi, accretion was recorded in sectors 21-26 and erosion in sectors 27-28. Near Marina di Pisa, coastal stabilisation/accretion was observed in sectors 98-101, and erosion in sector 105 (Figs. $1 \mathrm{~g}$, and $3 \mathrm{~b}$ );

ii) erosion in sector 65 , due to mega-cusp migration, which produces changes to shoreline position;

iii) in sectors 78-79, south of the Serchio river, due to mouth bar migration;

iv) in sectors $113-114$, by Livorno, where erosion was attributed to wave reflection process at the oblique port breakwater, built in 2000 (Cappietti et al., 2003).

Considering the two periods studied, the only unprotected accreting area is located at Marina di Pietrasanta, where littoral drift convergence can be observed (Pranzini, 2004). Most often, accretion

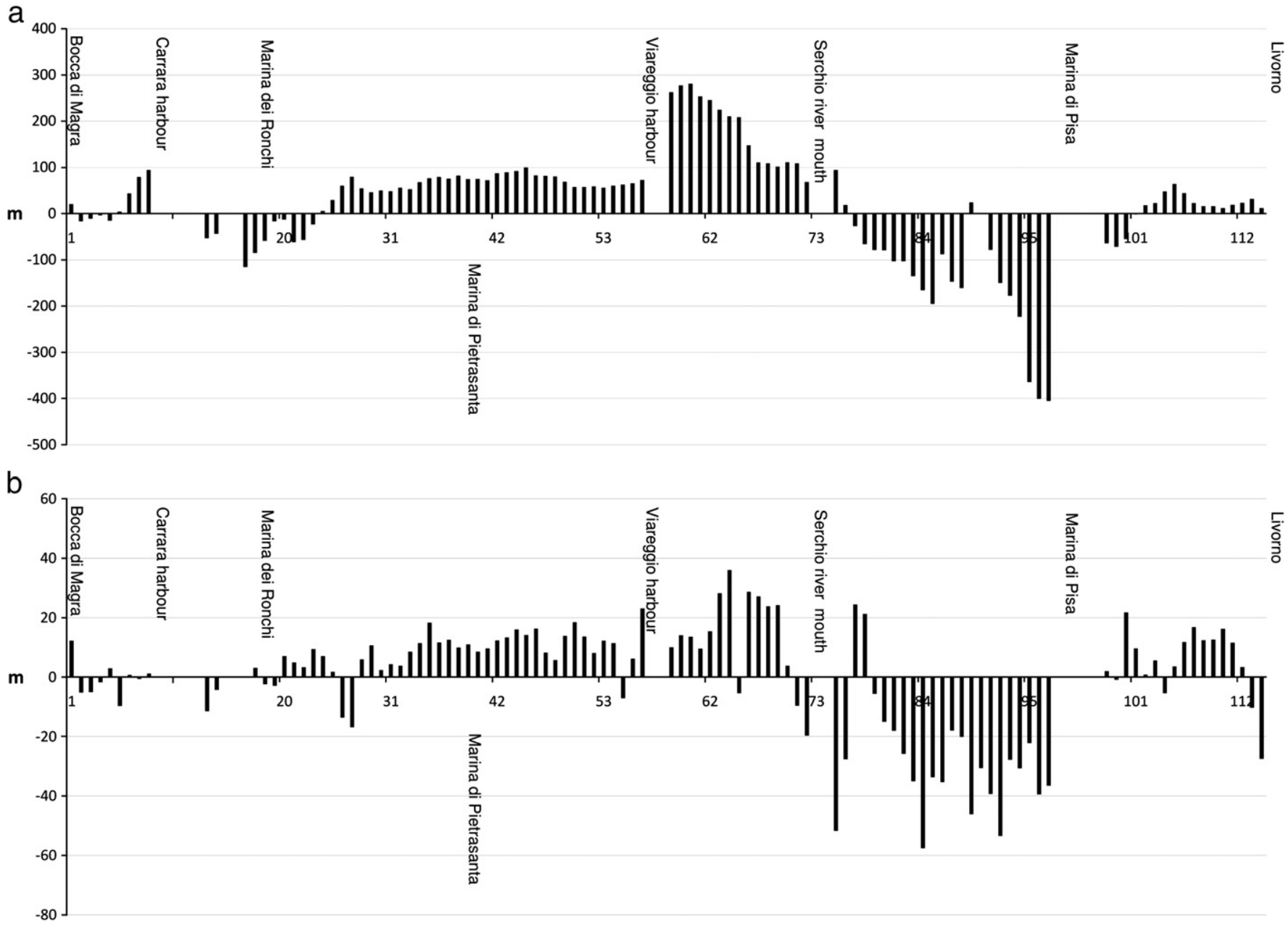

Fig. 3. Coastal evolution for the 1938-1997 (a) and 1997-2005 (b) periods. 
processes were evident updrift or in correspondence with protective structures and erosion was recorded downdrift. In fact breakwaters and groynes solved erosion problems-"locally", and not always-but shifted erosion downdrift, as observed in other coastal sectors by Jayappa et al. (2003), Zviely and Klein (2003), Phillips (2007) and Rodríguez and Dean (2009). Such a "solution", i.e., construction of hard engineering structures, did not follow any general, strategic erosion management plan (such as indicated by Hooke, 1998; Pethick, 2001). This exemplifies the inconsistencies that can be found among the ICZM EU recommendations of 2002, which present "local approach focus" and "strategic measures" as principles, without indicating the need for their coordination or integration (McKenna et al., 2008). The approach that had been used in the cases studied does oppose other European recommendations, which advocate working together with natural processes to ensure ecosystem integrity, considering a long-term perspective and the needs of present and future generations (Cooper and McLaughin, 1998; Cooper and McKenna, 2008; McKenna et al., 2008). Further, the continuous and extended use of both soft and hard engineering solutions transformed this coastal segment into a highly engineered coast which now depends completely on human intervention for its maintenance, as Cooper and Alonso (2006) and Cooper and McKenna (2008) have also reported for other parts of the world.

\subsection{Sedimentology}

Due to the length of the coastline, and to differences in natural and anthropogenic elements (i.e., rivers that drain basins of different lithology and sizes; harbours; and coastal structures) the mean grain size of sediments $(\mathrm{Mz})$ varies greatly, ranging from -3.09 to $3.60 \mathrm{phi}$, i.e. from fine pebbles to very fine sand according to Krumbein (1934). A cross-shore trend is evident (Fig. 4 a), with finer sediments at shallower depths, and outliers coming from the southernmost sector, where rocky offshore shoals are present (i.e., Meloria shoals, Fig. 1).

Sediments in the swash zone are highly variable (Fig. 4 b) between the Magra river mouth and Cinquale, where the beach comprises mixed sand and gravel sediments. Sediment sources are evident in the plot, with coarser material at the Arno river mouth (sand coarser than $0 \mathrm{phi}$ ) and at the Magra river mouth (gravel and granules of -3 to -1 phi).

As we move southward, a dimensional jump can be observed at Marina di Carrara harbour, which intercepts gravel. Such coarse sediments are occasionally present also to the south, in the most severely eroded area, and can be considered to be lag deposits of a beach fed with poorly sorted sediments prior to construction of the harbour. A small amount of this type of sediment can also be transported by minor creeks that discharge onto this coastal segment.

Sediments originating from the erosion of the Arno river delta move both southward (up to Livorno) and northward (up to Marina di Pietrasanta); the finest swash zone sediments are found in the latter. Finally, a 1-phi size jump occurs when sediments bypass Viareggio harbour.

\subsection{Beach slope and coastal trend}

Beach slope (Fig. 5) was measured between shoreline and depth of closure $(9.1 \mathrm{~m})$ at $500 \mathrm{~m}$-spaced profiles, corresponding to beach sectors used in the study of shoreline evolution (Fig. 1).

Beach slope exhibited high variability along this coast, with the highest value in front of the detached breakwaters at Marina di Pisa (1.7\%) and the lowest in the slowly accreting beach of Tirrenia, located $5 \mathrm{~km}$ south of the aforementioned town. A steep profile was also observed in the accreting area of Marina di Pietrasanta.

Jumps in the value of this parameter were evident downdrift of coastal structures: north of Marina di Pisa defences; at Fiume Morto jetty (between sector 85 and 86); at Viareggio harbour; and southward of Marina di Carrara.

Beach slope depends on wave climate and sediment characteristics (Carter, 1988). In the study area wave climate is homogeneous and variation in sediment characteristics is low, except for the swash zone (Fig. 4 a), which does not explain changes in nearshore slope; thus it is possible to state that slope variations are mainly related to changes in shoreline position.

A quantitative analysis of the position of the $9 \mathrm{~m}$ and $10 \mathrm{~m}$ bathymetric lines in the middle 1800s (French Navy, 1852), i.e., before the construction of harbours and protective structures, indicates that such bathymetric lines ran parallel to (and were almost homogeneously distant from) the shoreline. Deviations from this trend were (and are still) observed at Punta Bianca and Meloria shoals which play important structural control in the sense of Jackson et al. (2005), (Fig. 1). The $9.1 \mathrm{~m}$ bathymetric line, surveyed in 1997, exhibits the same trend as the $9 \mathrm{~m}$ and $10 \mathrm{~m}$ bathymetric lines-except in front of the Arno river mouth, where morphological changes are also due to gravity-induced processes (Bartolini and Pranzini, 1984); it runs parallel to the shoreline despite the presence of harbours (see $10 \mathrm{~m}$ bathymetric line in Fig. 1 for reference). The distance between the $9.1 \mathrm{~m}$ bathymetric line and the shoreline probably varied because of shoreline accretion or erosion due to natural and especially humaninduced processes that occurred in recent decades (Figs. 3, and 6). Hence, along the coast under study, beach response was clearly evident at the decadal time scale (with changes between $-404 \mathrm{~m}$ and $+281 \mathrm{~m}$ during the 1938-1997 period), but bathymetric response was probably very slow or null at the $9.1 \mathrm{~m}$ line.

This is evident comparing nearshore slope values and shoreline evolution from 1938 to 1997: slope is higher where the beach is accreting (Fig. 7), according to the model presented in Fig. 6, confirming general observations by Carter (1988) and more specific findings of Taylor et al. (2004) and Dornbusch et al. (2008) which related the widening of a dry beach to an increase in foreshore slope.

The eroding area between the Serchio and Arno rivers exhibited low slope values (0.6-1.0\%). High nearshore slope values (1.0-1.4\%) were observed in accreting areas at Marina di Pietrasanta and updrift (south) of Viareggio harbour (Fig. 7 a). Erosion areas exhibited low slopes and accretionary areas had high nearshore slopes; this is a clear and obvious trend that confirms the previous assumption of originally stable $9.1 \mathrm{~m}$ isobaths, at constant distance from the shoreline.

Low beach slope values recorded at the Magra river mouth and Tirrenia are linked to the protection by natural structures, which control the position of the $9.1 \mathrm{~m}$ bathymetric line, namely Punta Bianca promontory and Meloria shoals (Fig. 1). No significant shoreline variations were verified at these sites, and even structures (groynes) constructed at Marina di Carrara did not appear to affect the beach slope.

Low beach slope values observed downdrift (north) of the Viareggio harbour, corresponding to accretion areas and do not conform to the general trend. This discrepancy is due to the accretion trend observed during the 1938-1997 period, which results from artificial bypassing between 1954 and 1985 . This activity was interrupted when the shoreline south of the harbour reached the breakwater tip, and sediments could then bypass the harbour naturally.

Such "artificial" accretion masked the intense erosion trend initially recorded after the construction of the harbour (see how the shoreline is located landward regarding the updrift side, Fig. 1).

The relationship between the nearshore slope and shoreline evolution can also be confirmed when comparing the 1938 and 2005 shorelines. This shows overall beach surface accretion of approximately $806,000 \mathrm{~m}^{2}$, indicating that reduction in sediment input by rivers, responsible for severe erosion at the Arno and Magra rivers, was balanced by changes in beach slope. Retreating sectors produce more sediment per unit area of erosion than the amount of sediments required to create an identical accretion surface. In this 

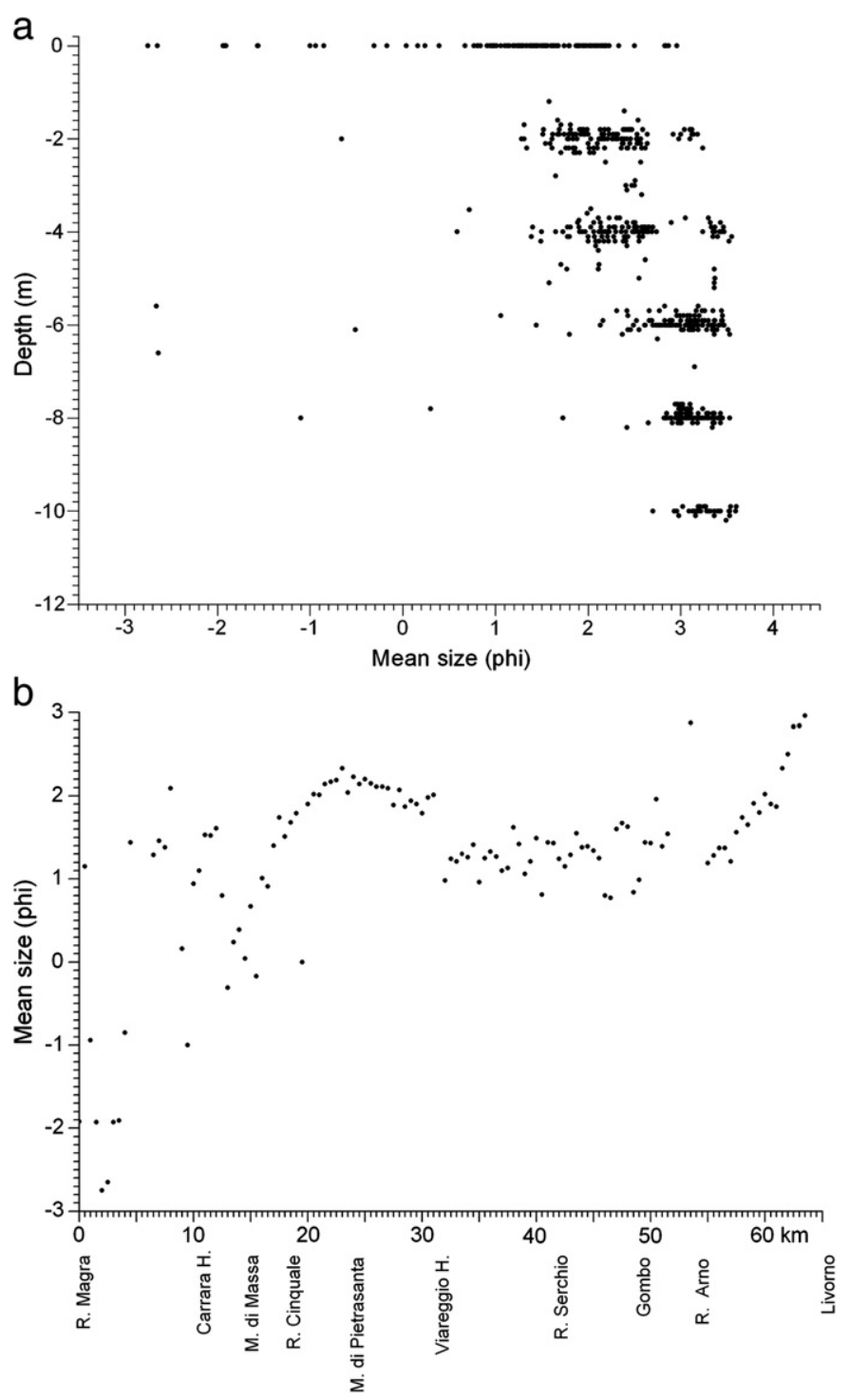

Fig. 4. Sediment mean grain size (Mz) vs depth (a) and along the swash zone (b) of the coast under study.

sense, the volume of sand from eroding areas (where beach slope decreases) that accumulates in an accreting area triggers the development of a wider beach due to an increase in slope, according to Fig. 6.

It is interesting to highlight that groynes do not produce considerable slope changes at Marina di Carrara and north of the Arno river mouth, whereas seawalls and breakwaters at Marina di
Massa, Gombo and Marina di Pisa caused the steepening of the beach slope due to erosion of the seafloor while the shoreline remained relatively stable. A quick reduction in slope values where structures are absent, i.e. at Marina de Ronchi (Fig. 7 a) is also evident, since structure-wave interactions produce scour processes, wave reflection and added turbulence due to waves breaking onto the structure (Pilkey and Dixon, 1996). This is a commonly observed trend: Funakoshi et al. (1994) recorded $1 \mathrm{~m}$ erosion near a submerged breakwater at Niigata (Japan), and Lamberti and Mancinelli (1996) recorded erosion landward and seaward of detached breakwaters in the Marche region (Italy). Frihy et al. (2008) analysed the distribution of erosion/accretion areas and nearshore slope up to circa $6 \mathrm{~m}$ water depth (approximately $1 \mathrm{~km}$ offshore) related to the presence of coastal structures along the Nile Delta. They all observed that shoreface slope-facing seawalls changed progressively over time, becoming more reflective; values of vertical deepening reached $2.5 \mathrm{~m}$ at a $100 \mathrm{~m}$ distance from the seawall during the $1982-2000$ period. Along the coasts of England and Wales, foreshore slope steepening has been related to artificial stabilisation of the high water line (Taylor et al., 2004; Dornbusch et al., 2008).

In the study area, breakwaters at Marina di Pisa, located at an initial depth of $2.5 \mathrm{~m}$, produced progressive deepening of up to $7 \mathrm{~m}$. Beach morphology was characterised by loss or reduction of bar systems in correspondence to the presence of protective structures. Limited energy dissipation occurs today during shoaling and waves break directly onto structures producing their scouring and, thus, requiring constant maintenance. More sediments are transported offshore than alongshore, causing erosion downdrift. Nearshore deepening was also observed in front of breakwaters at Marina di Pisa; at Marina di Massa rip currents trigged by water piling up behind the structures caused scouring of the seafloor between structures up to even greater depths $(11 \mathrm{~m})$.

Lesser et al. (2003) also recorded an increase in bed slope and in erosion (offshore and at the gap between submerged breakwaters, respectively) at Cortellazzo beach, in Italy.

\subsection{Coastal compartmentalisation}

Longshore distribution of erosion/accretion patterns for the 19381997 period appeared to be largely controlled by coastal compartmentalisation-understood as the existence of cells and sub-cells that constitute basic units into which the coast can be divided (Carter, 1988). According to Lowry and Carter (1982), cells and sub-cells are confined by limits which can be classified as "fixed"-, if presenting large-scale temporal stability since being associated with humanmade or natural structures (in this case the term "morphological cells" is used), or as "free"-, if their position changes in time in association with wave divergence and convergence processes caused by submerged features that can migrate with time and/or affect wave propagation, according to specific characteristics of approaching waves (the term "littoral cells" is then used, according to Carter,

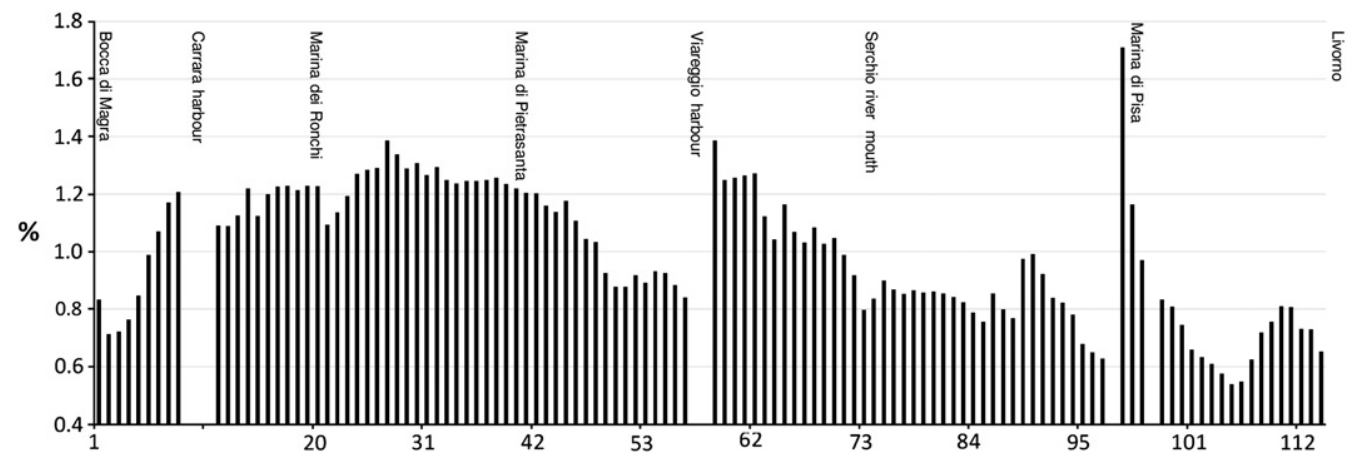

Fig. 5. Beach slope variations along the investigated littoral calculated according to the positions of the 1997 shoreline and the $9.1 \mathrm{~m}$ bathymetric line. 


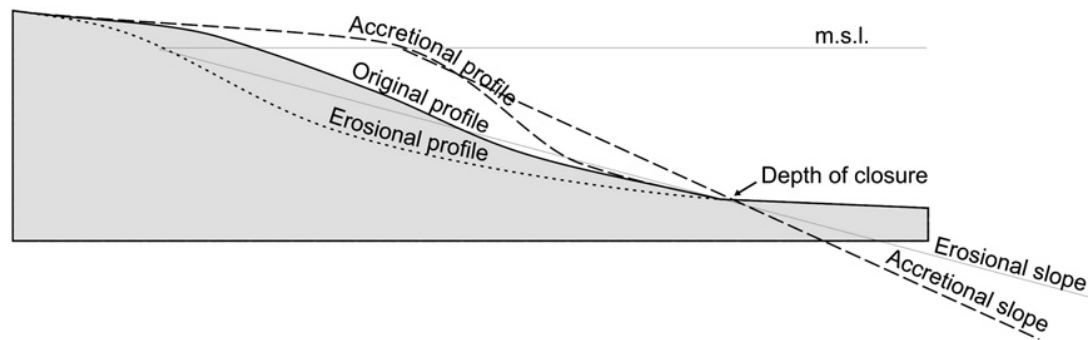

Fig. 6. Conceptual model of the beach slope change under eroding and accreting processes. In the figure eroded and accreted areas are identical.

1988; Bray et al., 1995; Frihy et al., 2008). Limits can also be classified as "divergent" (littoral drift divides), "meeting" or "convergent" (littoral drift converges), or "pulse" (when the accretion is recorded at one limit side and erosion at the other side); and as "absolute" (when they act as barrier to all sediments), or "partial" or "permeable" (when allowing bypassing). Concerning accreting or eroding zones close to cell limits, in this study they were respectively named as "e" and "a" following the proposals of May and Tanner (1973). In addition, a convergent limit characterises the downdrift part of a deposition area, i.e. an area of relatively high beach. In opposition, a divergent limit is located at the updrift side of shoreline erosion, where the beach is particularly low (Carter, 1988).

According to the previous assumptions, coastal compartmentalisation in the investigated area is forced by natural and human-made structures and by coastal orientation in relation to the approaching wave fronts. The effects of coastal embaymentisation on beach planform and surf zone circulation are evident as waves produce alongshore movement of sand, as a result of erosion in the updrift side of the cell and accumulation on the downdrift limit. In this study, following the terms proposed by May and Tanner (1973), the different parts of a cell were divided into areas of erosion ("b"), transition ("c", i.e., no changes because of beach planform pivoting) and accretion ("d").

Three principal cells, limited by fixed and free limits and containing sub-cells, can be described from north to south along the coast studied (Fig. 8).

The first cell is enclosed between i) the headland limiting the study area in the north (i.e. Punta Bianca promontory), which constitutes an absolute, fixed limit whose position did not change in recent

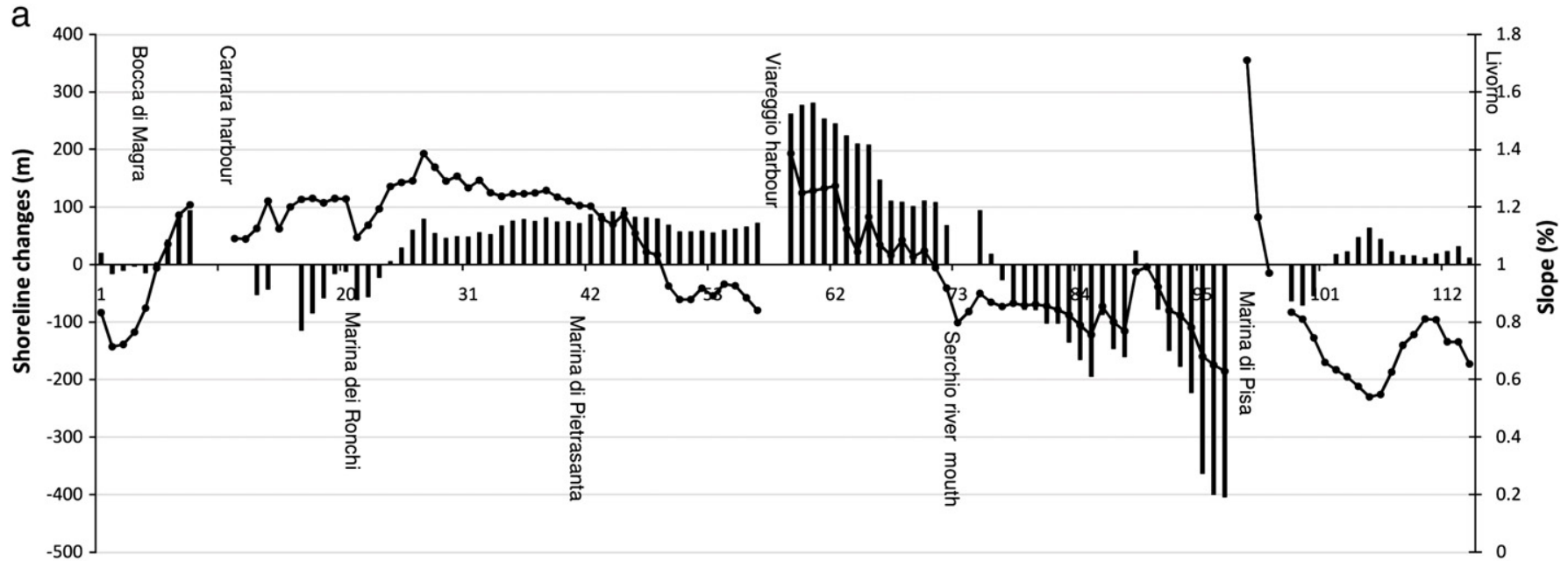

b

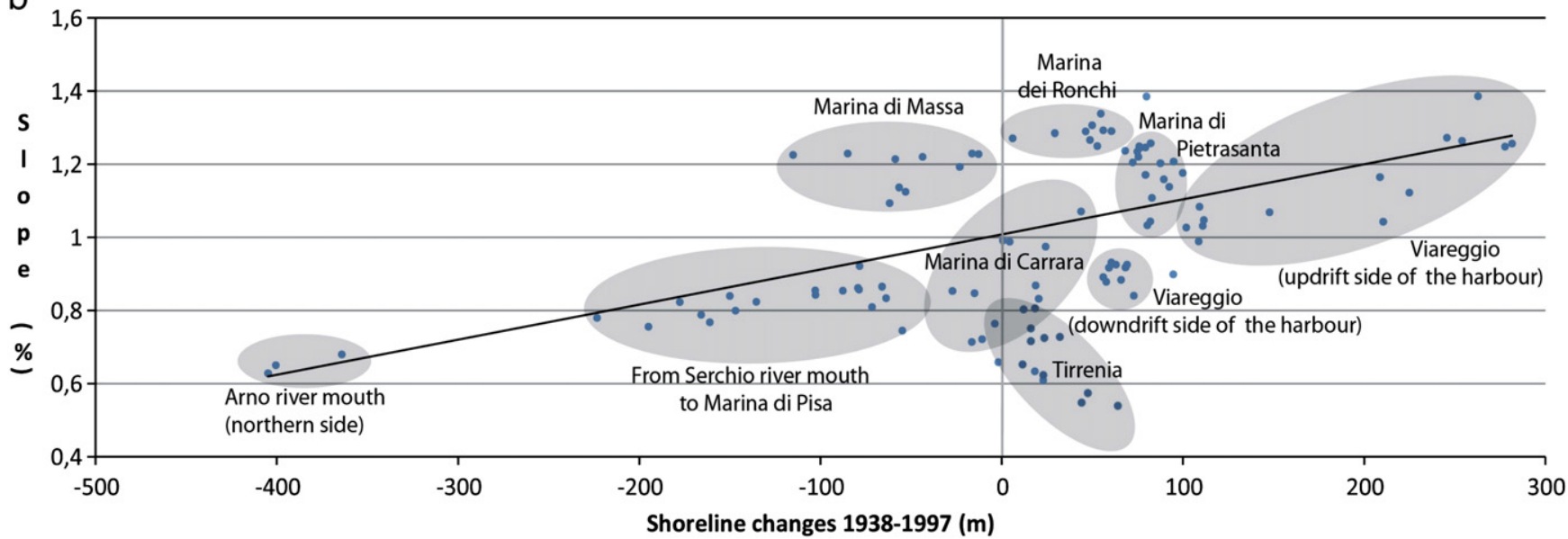

Fig. 7. Shoreline evolution from 1938 to 1997, and 1997 nearshore slope, in correspondence to the 114 coastal sectors studied (a) and the relationship between shoreline evolution and nearshore slope (b). 


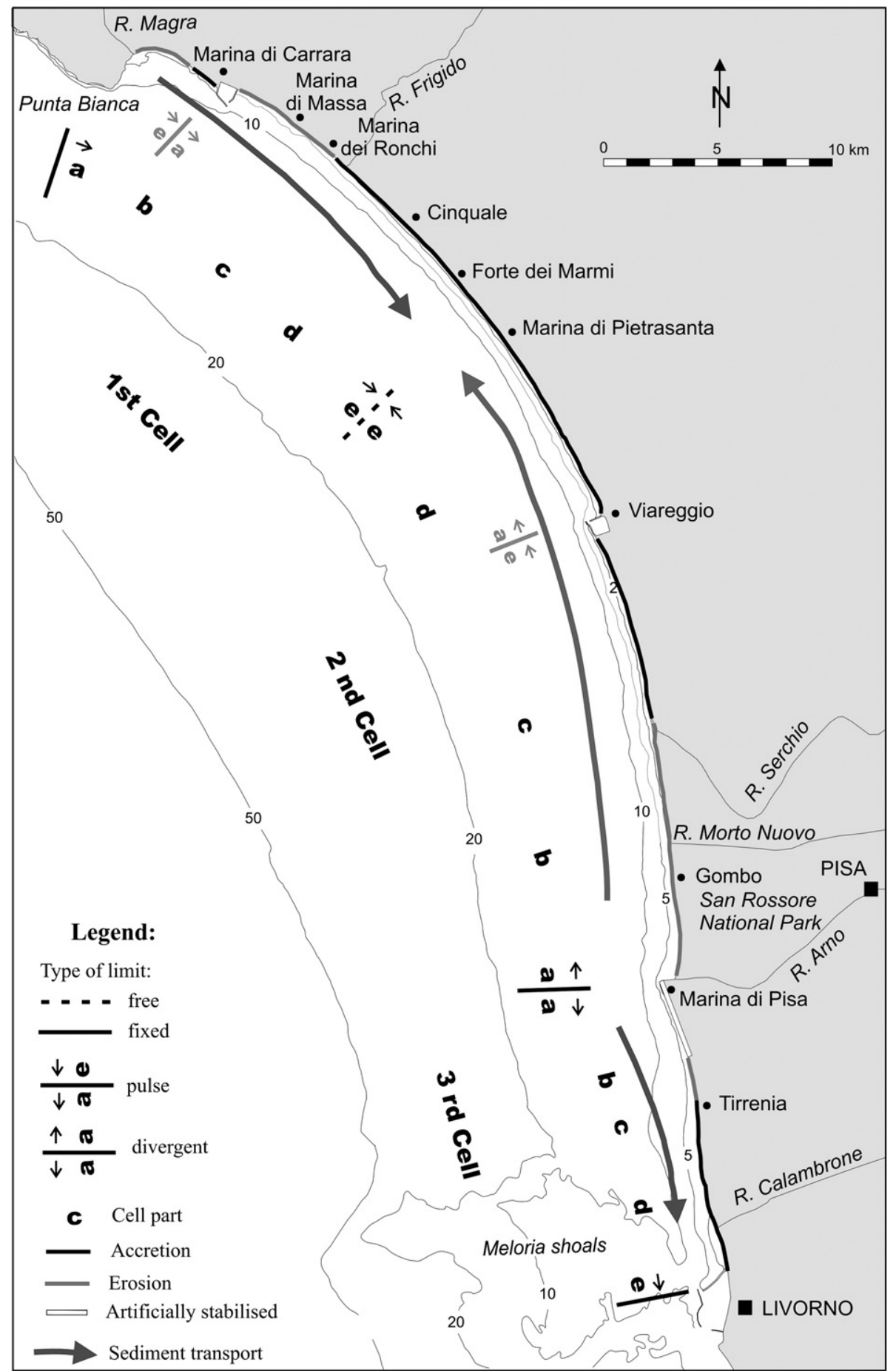

Fig. 8. Erosion/accretion areas, sediment transport, characteristics of limits and parts of major cells-limits of secondary cells in grey.

centuries, and ii) a limit at Marina di Pietrasanta sector (Fig. 8), which acts as a free, convergent limit formed due to convergence interaction of two opposite drifts, as confirmed by morphological, sedimentological, petrographic and hydraulic evidences (Aminti et al., 1999; Pranzini, 2004). The distribution of erosion/accretion areas (Fig. 3 a) reflects this sediment circulation pattern (Fig. 8). Bocca di Magra, Marina di Massa and Marina dei Ronchi represent the northern erosive part of the cell ("b", Fig. 8) and Marina di Pietrasanta, the accreting area ("d"); the transition zone is located south of Marina dei Ronchi ("c", Figs. 3 a, and 8). The transition point has the same meaning of nodal points described by Frihy et al. (2008) for the Nile river delta.
The second cell is limited by the Marina di Pietrasanta limit and the Arno river mouth which, due to a cuspate morphology, forms a divergent, fixed limit that did not migrate in recent centuries since it had been artificially stabilised in the early 1900s. Within the cell, accretion areas ("d") are located at Marina di Pietrasanta and updrift (south) of Viareggio harbour; erosion areas are located on the northern part of the Arno river delta ("b"); and the transition limit is located at the Serchio river mouth ("c", Fig. 8).

The third cell is enclosed between the Arno river mouth and the port of Livorno, which works as an absolute fixed limit. In this cell, erosion is observed at Marina di Pisa ("b"), and accretion at Tirrenia ("d", Fig. 8). Near the port of Livorno wave reflection by oblique 
structures built in 2000 currently induces a local flow reversal (Cappietti et al., 2003).

It is important to highlight that these cells are limited by natural structures, whereas human-made structures interfere with natural sediment transport within major cells creating small sub-cells, as observed by Bray et al. (1995) and Bray (1997) in South England, and by Frihy et al. (2008) in the Nile river delta. This opposes the findings of Anfuso et al. (2007) and Anfuso and Martinez (2009), which indicated how major cells were defined by human-made structures in the northern Mediterranean coast of Morocco and southern Sicily (Italy).

The most important structures are the harbours of Carrara and Viareggio (Fig. 8) which constitute artificial, fixed pulse limits (as defined by Bray et al., 1995). They allow for periodic, unidirectional transport that, according to field observations and surveys, occurs along narrow zones parallel to the shoreline, extending to varying depths, depending on structure dimensions, wave conditions and seafloor morphology. Bypassing over such limits can be due to bedload sand transport onto longshore bars (at Viareggio) or, secondarily, in the nearshore zone (at Carrara). In both cases, only fine sediments may bypass the structures, which act as a one-way valve that allows transport to occur in one predominant direction only (as observed in west Dorset, UK, by Bray, 1997). This is confirmed by granulometric analyses, as previously explained (Fig. 4).

It is important to note how human-made structures control the migration of transition points ("c") within major cells. The construction of Carrara harbour and defensive structures downdrift, respectively produced sediment impoundment and coastal armouring, thus interrupting the supply of sediment to the areas downdrift (Runyan and Griggs, 2003; Rodríguez and Dean, 2009); it also caused the migration of the "c" point to approximately $4.3 \mathrm{~km}$ southward (equilibrium point in 1938-1954 shorelines vs the same point in 1997-2005 shorelines).

The position of "c" point within the second cell (Fig. 8) is not related to the presence of very local protective structures. The observed migration (to approximately $7 \mathrm{~km}$ northward, considering the same time intervals) can be explained by the conceptual model of cuspate delta erosion proposed by Pranzini (1989).

\section{Final considerations}

Following EU recommendations on ICZM, understanding of coastal processes and evolution in the area under study is necessary for the sustainable management of coastal sediments, minimising impacts of protective structures built in the past whereas properly evaluating the adequacy of the present and future structural interventions. A proper response to problems associated to coastal erosion can only be articulated where knowledge of coastal dynamics, characteristics of cells and sub-cells, and linking pathways are available. At the strategic level, it is sufficient to identify independent cells and partially dependent sub-cells for the definition of shoreline management units.

In the area investigated, there is relatively scarce input of sediments into the coastal system and the net alongshore flow; coastal compartmentalisation thus acquires more importance in the processing of sediments. Sediments in this area move along three main littoral cells, limited by natural (free and fixed) boundaries, and divided into sub-cells due to the construction of Carrara and Viareggio harbours in the beginning of the 20th century.

Concerning beach evolution over a decadal time scale, beach response corresponded to the presence of natural limits and harbours. Structures produced intense updrift accretion and downdrift erosion, but bathymetric response at $9.1 \mathrm{~m}$ water depth was reduced or null. As a result, beach slope varied slightly, increasing values in accreting areas and decreasing in erosional areas. Such behaviour has important morphological implications. Beach accretion is essentially limited to the upper profile whereas beach erosion affects the entire profile as eroding areas produce more sediment per unit retreat area than those necessary for the reverse process in the accreting sites.

A large increase in the nearshore slope was observed in front of breakwaters and seawalls that had been constructed downdrift of harbours to halt erosion processes. Nearshore deepening led to a progressive increase in wave-related processes and scouring effects.

The complete restoration of the natural system needs to be viewed as a long-term objective that must not be replaced by any short-term remedial actions. In the context of littoral cell management strategy for this area, sediments accumulated updrift of the harbour of Carrara should be bypassed to fill the beach of Marina di Massa. Concerning the harbour of Viareggio, sediments now bypassing its entrance through the development of a bar should be dredged and deposited in the eroding area located between the Arno and Serchio river mouths. Stakeholders from Viareggio have accepted this proposal since they have been informed that this material will return to their beach, where it could be useful in the future. The use of dredged sediments to fill the eroding area in the first cell has not been approved since those sediments would never return to Viareggio due to the impossibility of overpassing the Marina di Pietrasanta convergence point.

\section{Acknowledgments}

This work is a contribution to the Andalusia Research Group PAI RNM-328 and was partially conducted at the CACYTMAR Research Centre (Junta de Andalucía-UCA).

\section{References}

Aminti, P.L., Iannotta, P., Pranzini, E., 1999. Morfodinamica di un sistema costiero intensamente protetto: il litorale di Marina di Massa. Proc. Conf.. Il rischio idrogeologico e la difesa del suolo. Accademia Nazionale dei Lincei, Roma, Italy.

Aminti, P.L., Cipriani, L.E., Pranzini, E., 2003. 'Back to the beach': converting seawalls into gravel beaches. In: Goudas, C., et al. (Ed.), Soft Shore Protection, Coastal Systems and Continental Margins, Volume 7. Kluwer Academic Publishers, pp. 261-274.

Aminti, P.L., Cammelli, C., Cappietti, L., Jackson, N.L., Nordstrom, K.F., Pranzini, E., 2004. Evaluation of beach response to submerged groin construction at Marina di Ronchi, Italy, using field data and a numerical simulation model. Journal of Coastal Research $33,99-120$

Anfuso, G., Martinez, J.A., 2009. Assessment of coastal vulnerability through the use of GIS tools in South Sicily (Italy). Environmental Management 43, 533-545.

Anfuso, G., Martínez, J.A., Nachite, D., Benavente, J., Macias, A., 2007. Morphological characteristics and medium-term evolution of the beaches between Ceuta and Cabo Negro (Morocco). Environmental Geology 52, 933-946.

Bartolini, C., Pranzini, E., 1984. Fan delta erosion in southern Tuscany as evaluated from hydrographic surveys of 1883 and the late '70. Marine Geology 62, 181-187.

Bartolini, C., Cipriani, L.E., Pranzini, E., Sargentini, M., 1989. Caratteristiche geomorfologiche ed evoluzione della linea di riva del litorale toscano e criteri di lettura. "Coste toscane", Regione Toscana, pp. 33-56.

Becchi, I., Paris, E., 1989. Il corso dell'Arno e la sua evoluzione storica. Acqua Aria 6, 645-652.

Berlanga, C., Ruiz, A., 2002. Land use mapping and change detection in the coastal zone of northwest Mexico using remote sensing techniques. Journal of Coastal Research $18,514-522$.

Bowman, D., Pranzini, E., 2003. Reversed response within a segmented detached breakwater-the Gombo case, Tuscany coast, Italy. Coastal Engineering 49, 263-274.

Bray, M., 1997. Episodic shingle supply and the modified development of Chesil Beach, England. Journal of Coastal Research 13 (4), 1035-1049.

Bray, M., Carter, D., Hooke, J., 1991. Coastal sediment transport study. Report to SCOPAC, Department of Geography, Portsmouth Polytechnic. 498 pp.

Bray, M., Carter, D., Hooke, J., 1995. Littoral cell definition and budgets for central southern England. Journal Coastal Research 11, 381-400.

Cammelli, C., Jackson, N.L., Nordstrom, K.F., Pranzini, E., 2006. Assessment of a gravelnourishment project fronting a seawall at Marina di Pisa, Italy. Journal of Coastal Research S.I. 39, 770-775.

Cappietti, L., Cammelli, C., Farrell, E., Ferri, S., Aminti, P.L., Pranzini, E., 2003. A case of updrift erosion induced by a harbour breakwater. Medcoast 2003, Ravenna, pp. 1707-1718.

Carter, R.W.G., 1988. Coastal Environments. Academic Press. 617 pp.

Cavazza, S., 1984. Regionalizzazione geomorfologica del trasporto solido in sospensione dei corsi d'acqua tra il Magra e l'Ombrone. Atti della Società Toscana di Scienze Naturali, Memorie Serie A 91, 119-132.

Cipriani, L.E., Pelliccia, F., Pranzini, E., 1999. Beach nourishment with nearshore sediments in a highly protected coast. MEDCOAST'99, Antalya, Turchia, pp. 1579-1590. 
Cipriani, L.E., Ferri, S., Iannotta, P., Paolieri, F., Pranzini, E., 2001. Morfologia dinamica dei sedimenti del litorale della Toscana settentrionale. Studi Costieri $4,119-156$

Cooper, J.A.G., Alonso, I., 2006. Natural and anthropic coasts: challenges for coastal management in Spain. Journal of Coastal Research Special Issue 48, 1-7.

Cooper, J., McLaughin, S., 1998. Contemporary multidisciplinary approaches to coastal classification and environmental risk analysis. Journal of Coastal Research 14, 512-524.

Cooper, J.A.G., McKenna, J., 2008. Working with natural processes: the challenge for coastal protection strategies. Geographical Journal 174, 315-331.

Cooper, N., Pethick, J., 2005. Sediment budget approach to addressing coastal erosion problems in St. Ouen's Bay, Jersey, Channel Island. Journal of Coastal Research 21, $112-122$.

Crowell, M., Leatherman, S.P., Buckley, M., 1993. Shore-line change rate analysis: long term versus short term data. Shore and Beach 61, 13-20.

De Filippi, G.L., Duchini, E., Pranzini, E., 2008. Closure depth estimation along the Tuscan coast aimed at short and long term coastal monitoring. Beach Erosion Monitoring, a cura di E. Pranzini e L. Wetzel, BeachMed-e/OpTIMAL Project, Nuova Grafica Fiorentina, Firenze, pp. 33-50.

Dipartimento di Scienze della Terra-Università di Firenze, 1989. Carta delle linee di riva in scala 1:5.000 In: "Coste toscane", Regione Toscana, Firenze. 14 sheets.

Dolan, R., Fester, M.S., Holme, S.J., 1991. Temporal analysis of shoreline recession and accretion. Journal of Coastal Research 7, 723-744.

Dornbusch, U., Williams, R., Moses, C., Robinson, D., 2008. Foreshore narrowing along the coast of Southeast England, UK-A reevaluation. Journal of Coastal Research 24 14-24.

European Centre for Medium-range Weather Forecast, 2008. http://www.ecmwf/.int.

Ferri, S., Pelliccia, F., Pranzini, E., Rizzo, M., Vitale, G., 2008. Prima risposta della spiaggia di Marina di Carrara ad un ripascimento artificiale non protetto. Studi Costieri 15, $3-20$.

Fischer, D., 1985. Responses to coastal threats: toward an integrated strategy. Journal of Coastal Research 1, 383-388.

Folk, R.L., Ward, W.C., 1957. Brazos River Bar. A study in the significance of grain size parameters. Journal of Sedimentary Petrology 27, 3-26.

French Navy, 1852. Carte particulière des Côtes d'Italie (Duchés de Modène, de Lucques et G. ${ }^{d}$ D. é de Toscane). Partie comprise entre le Golfe de La Spezia et l'embouchure de l'Arno. Levée en 1846. Scale 1:50.000.

Frihy, O., Shereet, S., El Banna, M., 2008. Pattern of beach erosion and scour depth along the rosetta promontory and their effect on the existing protection works, Nile Delta, Egypt. Journal of Coastal Research 24, 857-866.

Funakoshi, H., Shiozawa, T., Tadokoro, T., Tsuda, S., 1994. Drifting characteristics of littoral sand around submerged breakwater. Proc. Inter. Conf. On hydro-technical Engineering for Port and Harbour Construction, Yokosuka, Japan, pp. 1157-1178.

Gandolfi, G., Paganelli, L., 1975. Il litorale pisano-versiliese (Area campione Alto Tirreno). Composizione, provenienza e dispersione delle sabbie. Bollettino della Società Geologica Italiana 94, 1273-1295.

Garzanti, E., Canclini, S., Moretti Foggia, F., Petrella, N., 2001. Upraveling magmatic and orogenic provenances in modern sands: the back-arc side of the Apennine thrustbelt (Italy). Journal of Sedimentary Petrology 72, 2-17.

Hallermeier, R.J., 1981. A profile zonation for seasonal sand beaches from wave climate. Coastal Engineering 4, 253-277.

Hooke, J., 1998. Coastal defense and earth science conservation. The Geological Society. 270 pp.
Istituto Idrografico della Marina (2003)-Tavole di Marea 2003. Genova, pp. 112. Jackson, D., Cooper, A., Del Rio, L., 2005. Geological control of beach morphodynamic state. Marine Geology 216, 297-314

Jayappa, K.S., Vijaya, G.T., Subrahmanya, K.R., 2003. Influence of coastal structures on the beaches of Southern Karnataka, India. Journal Coastal Research 19, 389-408.

Krumbein, W.C., 1934. Size frequency distributions of sediments. Journal of Sedimentary Petrology 4, 65-77.

Lamberti, A., Mancinelli, A., 1996. Italian experience on submerged barriers as beach defence structures. Proc. 25th International Conference on Coastal engineering. ASCE, Orlando, USA, pp. 2352-2365.

Lesser, G.R., Vroeg, J.H., Roelvink, J.A., de Gerloni, M., Ardone, V., 2003. Modelling the morphological impact of submerged offshore breakwaters. Proc. Coastal Sediments '03. World Scientific Publishing Co., Florida, USA. On CD-Rom.

Lowry, P., Carter, R.W.G., 1982. Computer simulation and delimitation of littoral drift cells on the south coast of Co. Wexford, Ireland. Journal Heart Science R. Dublin Soc. 4, 121-132.

May, J.P., Tanner, W.F., 1973. The littoral power gradient and shoreline changes. In Coates, D.R. (Ed.), Coastal Geomorphology, pp. 43-61.

McKenna, J., Cooper, J.A.G., O'Hagan, A.M., 2008. Managing by principle: a critical assessment of the EU principles of ICZM. Marine Policy 32, 941-955.

Pethick, J., 2001. Coastal management and sea level rise. Catena 42 (2-4), 307-322.

Phillips, M., 2007. Beach response to a total exclusion barrage: Cardiff Bay, South Wales, UK. Journal of Coastal Research 23, 794-805.

Pilkey, O., Dixon, K., 1996. The Corps and the Shore. Island Press. 272 pp.

Pranzini, E., 1989. A model for cuspate delta erosion. 6th Symp. on Coastal and Ocean Management/ASCE. Charleston, SC. Coastal Zone '89, pp. 4345-4357.

Pranzini, E., 1994. Bilancio sedimentario ed evoluzione storica delle spiagge. Il Quaternario 7, 197-202.

Pranzini, E., 2001. Updrift river mouth migration on cuspate deltas: two examples from the coast of Tuscany (Italy). Geomorphology 1-2, 125-132.

Pranzini, E., 2004. Caratteristiche morfologiche e sedimentologiche di una zona di convergenza del trasporto litoraneo (Versilia, Toscana). Studi Costieri 8, 135-149.

Preti, M., 2009. Stato del litorale emiliano-romagnolo nell'anno 2007 e piano decennale di gestione. ARPA-Emilia-Romagna, Bologna, p. 270.

Regione Toscana (2006)-Studio e ricerca per l'implementazione del quadro conoscitivo della costa toscana nell'ambito del Piano Regionale di Gestione integrata della Costa. Unpublished report.

Rodríguez, E., Dean, R., 2009. A sediment budget analysis and management strategy for fort Piece Inlet, Florida. Journal of Coastal Research 25, 870-883.

Runyan, K., Griggs, G., 2003. The effects of armouring sea cliffs on the natural sand supply to the beaches of California. Journal of Coastal Research 19, 336-347.

Sargentini, M., Trambusti, M., Cipriani, L.E., Morelli, F., Regoli, C., 2004. Il Piano Regionale di Gestione Integrata della Costa. Erosione Costiera. Edifir, Firenze, pp. 7-74.

Taylor, J.A., Murdock, A.P., Pontee, N.I., 2004. A macroscale analysis of coasta steepening around the coast of England and Wales. The Geographical Journal $170,179-188$

WAM-Development and Implementation Group, 1988. The WAM model-a third generation ocean wave prediction model. Journal Physical Oceanography 18 1775-1810.

Zviely, D., Klein, M., 2003. The environmental impact of the Gaza strip coastal constructions. Journal of Coastal Research 19, 1122-1127. 